\title{
Double degree master program: Optical Design
}

\begin{abstract}
Alexey Bakholdin, Malgorzata Kujawinska, Irina Livshits, Adam Styk, Anna Voznesenskaya, et al.
\end{abstract}

Alexey Bakholdin, Malgorzata Kujawinska, Irina Livshits, Adam Styk, Anna Voznesenskaya, Kseniia Ezhova, Elena Ermolayeva, Tatiana Ivanova, Galina Romanova, Nadezhda Tolstoba, "Double degree master program: Optical Design," Proc. SPIE 9793, Education and Training in Optics and Photonics: ETOP 2015, 979307 (8 October 2015); doi: 10.1117/12.2223055

SPIE Event: Education and Training in Optics and Photonics: ETOP 2015, 2015, Bordeaux, France 


\title{
Double degree master program "Optical design"
}

\author{
Alexey Bakholdin ${ }^{\mathrm{a}}$, Malgorzata Kujawinska ${ }^{\mathrm{b}}$, Irina Livshits ${ }^{\mathrm{a}}$, Adam Styk ${ }^{\mathrm{b}}$, Anna Voznesenskaya ${ }^{* a}$, \\ Kseniia Ezhova ${ }^{a}$, Elena Ermolayeva ${ }^{a}$, Tatiana Ivanova ${ }^{a}$, Galina Romanova ${ }^{a}$, Nadezhda Tolstoba ${ }^{a}$ \\ ${ }^{a}$ ITMO University, 49 Kronverksky av., St.Petersburg, 197101, Russian Federation; ${ }^{b}$ Warsaw \\ University of Technology, the Faculty of Mechatronics, Pl. Politechniki 1, 00-661 Warsaw, Poland
}

\begin{abstract}
Modern tendencies of higher education require development of master programs providing achievement of learning outcomes corresponding to quickly variable job market needs. ITMO University represented by Applied and Computer Optics Department and Optical Design and Testing Laboratory jointly with Warsaw University of Technology represented by the Institute of Micromechanics and Photonics at The Faculty of Mechatronics have developed a novel international master double-degree program "Optical Design" accumulating the expertise of both universities including experienced teaching staff, educational technologies, and experimental resources. The program presents studies targeting research and professional activities in high-tech fields connected with optical and optoelectronics devices, optical engineering, numerical methods and computer technologies. This master program deals with the design of optical systems of various types, assemblies and layouts using computer modeling means; investigation of light distribution phenomena; image modeling and formation; development of optical methods for image analysis and optical metrology including optical testing, materials characterization, NDT and industrial control and monitoring. The goal of this program is training a graduate capable to solve a wide range of research and engineering tasks in optical design and metrology leading to modern manufacturing and innovation. Variability of the program structure provides its flexibility and adoption according to current job market demands and personal learning paths for each student. In addition considerable proportion of internship and research expands practical skills. Some special features of the "Optical Design" program which implements the best practices of both Universities, the challenges and lessons learnt during its realization are presented in the paper.
\end{abstract}

Keywords: master program, double degree program, education in optics, optical design, optical metrology

\section{BACKGROUND AND MOTIVATION}

Recently, ITMO University has developed a sustainable collaborative network with research and educational partners around the globe. ITMO University collaborates with over 100 institutions on a variety of educational projects, double degrees, short and long-term learning projects (Fig.1). ITMO participates in a variety of international programs, including Fulbright, Erasmus Mundus, Photonics21, DAAD and Unesco-Unevoc [1].

Education globalization and internalization are implemented mainly according to the Excellence Program "National Research University" and the program for enhancing the competitiveness of the ITMO University among the world's leading research and educational centers " 5 to 100 ". IT and Photonics and Optics have been selected as the most "powerful" educational fields for the international growth.

The educational and research school on optical design and engineering is among the oldest in ITMO. It was established in 1930s by Professor Churilovsky. Nowadays, ITMO University is a leading Russian center for education and research in applied optics. This explains a strong interest for cooperation on the part of many well-known world universities.

On the other hand, the optics group at Warsaw University of Technology is internationally recognized in the field of optical metrology and development of measurements systems. The education and research in optics started back in 1953, first at the Faculty of Precision Mechanics (since 1996 the Faculty of Mechatronics) and since the beginning it has been the leading Polish center in optical and photonics engineering. Specifically, the Faculty of Mechatronics has participated in Erasmus Mundus Masters (EMM) "OpSciTech: Optics in Science and Technology" [2] since 2009. The OpSciTech consortium (Institut d'Optique and Universite Paris-Sud11 (France), Imperial College London (The United Kingdom),

*voznesenskaya@mail.ifmo.ru

Education and Training in Optics and Photonics: ETOP 2015, edited by Eric Cormier, Laurent Sarger Proc. of SPIE Vol. 9793, 979307 • @ 2015 SPIE, IEEE, OSA, ICO · doi: 10.1117/12.2223055 
Delft University of Technology (The Netherlands), Friedrich Schiller University Jena (Germany) and Warsaw University of Technology (Poland)) have provided different tracks in optical engineering education. ITMO has also been involved in providing invited lecturers on optical design for WUT and Delft Technical University. The experience gained during running this course has provided a perfect background for establishing the Master double-degree program in "Optical Design".

\section{DDP CONCEPT AND STRUCTURE}

The department of Applied and Computer Optics (ACO) of ITMO University has developed a roadmap for international advancement. Within the framework of this roadmap an access to the international market of educational services by way of cooperation with global universities, research and educational institutions and development of joint educational programs has been proposed as a key goal and prospective progress direction.

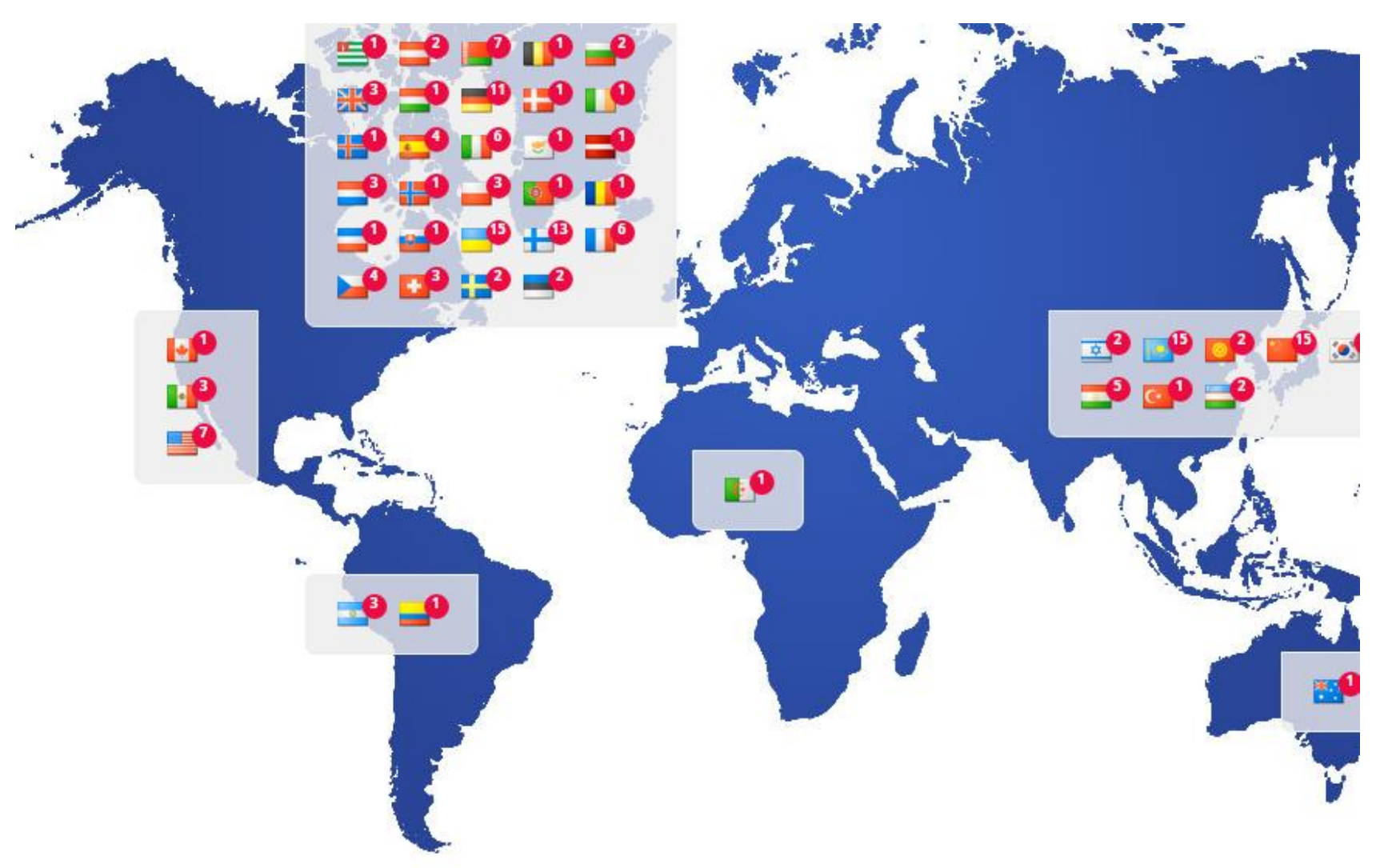

Figure 1. Global partners of ITMO University [1]

Similarly WUT has realized since 2000 the intensive process of internationalization [3] which includes development of several courses with English as the language of instruction followed by signing of numerous double degree master programs in the field of informatics, aviation, mathematics, automatics and robotics and others with partners from the USA, Italy, France, Germany, Spain, South Korea, Ukraine and Russia.

In 2013 there was developed a joint double-degree master program "Optical Design" (DDP) between ACO and Warsaw University of Technology - WUT. The DDP was developed according to the Law on Education in Russian Federation N 273-Ф3, from Dec.29, 2012 and ITMO Statement on the network realization of educational programs including international cooperative educational programs. The DDP prescribed equal studies in ITMO and WUT and was regulated by the agreement on joint educational activities, joint curricula and learning schedule, mutual recognition of the admittance procedures and attestation, common commission on thesis defenses, and two diplomas. 
The DDP aims to prepare world-class highly qualified experts in the growing field of optical engineering synthesizing scientific and professional expertise of ITMO and WUT and providing students with in-built mobility periods in partner universities.

The developed master program is innovative, sophisticated and modular. It focuses on professional competence development in the optical design area. The program provides learning oriented for scientific and professional activities in high-tech areas connected with optical and optoelectronics devices, optical technologies, math's and computer methods. It is built on the scientific basis of applied and computer optics, photonic technologies, optoelectronics and CAD appliances and is oriented at the optical system design with application of computer modeling instruments, optical phenomena investigation, theory and methods of image formation, development of methods for optical performance analysis and testing; design of optical layouts, planning of experiments, optical measurements and investigations. The authors of the program aimed to get a competitive graduate to accomplish a wide range of optical tasks connected with design and manufacturing of optical systems and devices.

The program relevance is in the implementation of a multilateral master learning approach. A synthetic and variable approach to the curricula development and content provides a flexible program modification, allows taking into consideration current job market demands and responding adequately to its changes.

A synthesis of a unique teaching staff experience in education and research of both partners and combination of advanced educational technologies and computer modeling methods (ITMO) and experimental studies in modern laboratories (WUT) is a special feature of the master program.

The total workload of the program is 120 ECTS (Fig.2). The program includes general scientific and professional modules, which consists of core and elective courses. Elective courses compose $30 \%$ of the courses and provide development of individual learning paths and program's adoption. A considerable load of the student's research and internship (60 ECTS) provides the project and practice-oriented concept of studies and implements the professional experience growth.

The DDP structure and list of courses is shown in Fig.3. Training methods include lectures, laboratory experiments, master-classes, seminars, research, projects, internship, and independent work.

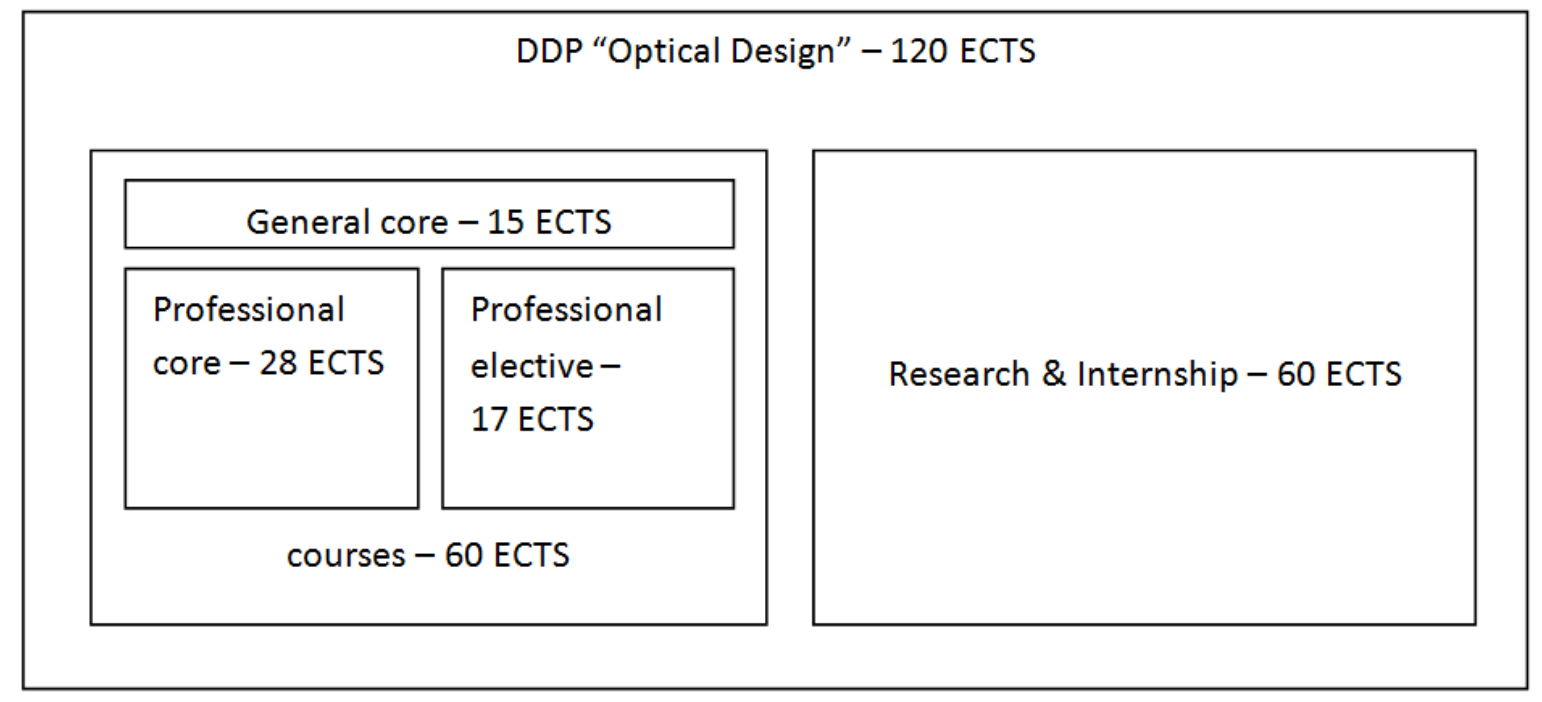

Figure 2. DDP modules

\section{DDP REALIZATION AND FIRST OUTCOMES}

The first enrollment of students for this program was in 2013 in the ITMO University (4 students). During the first academic year students took courses according to the curricula. The students showed a high level of motivation for learning and research, they successfully passed the IELTS exam. During the second academic year the students are taught in the WUT. Despite an unusual learning and social environment, the students passed the exams well and are now working on their final papers which are to be defended in the WUT before a joint board of both Universities via Skype. 


\begin{tabular}{|c|c|c|c|c|c|c|c|}
\hline $\begin{array}{l}\text { Structu } \\
1^{\text {st }} \text { YEAR } \\
\text { St.Petersk }\end{array}$ & of th & \multicolumn{5}{|c|}{ Structure of the DDP "Optical Design" } & \\
\hline \multirow[t]{3}{*}{1 semester } & 30 & $\begin{array}{l}\text { CALS strategy in } \\
\text { optical engineering } \\
\text { Choose } 1 \text { of } 2 \text { courses }\end{array}$ & 4 & $\begin{array}{l}\text { Optical system } \\
\text { design } \\
\text { Choose } 1 \text { of } 2 \text { courses }\end{array}$ & 6 & Research project & 12 \\
\hline & & $\begin{array}{l}\text { Optical image } \\
\text { modeling }\end{array}$ & 5 & $\begin{array}{l}\text { Project } \\
\text { management }\end{array}$ & 3 & & \\
\hline & & $\begin{array}{l}\text { Design of optical } \\
\text { devices and } \\
\text { components }\end{array}$ & 5 & $\begin{array}{l}\text { Philosophical } \\
\text { anthropology and } \\
\text { social philosophy }\end{array}$ & 3 & & \\
\hline \multirow[t]{4}{*}{2 semester } & 30 & $\begin{array}{l}\text { Composing and } \\
\text { optical systems } \\
\text { design }\end{array}$ & 3 & English & 3 & $\begin{array}{l}\text { Research project } \\
\text { Internship }\end{array}$ & $\begin{array}{c}6 \\
12\end{array}$ \\
\hline & & Choose 1 of 2 courses & & Choose 1 of 2 courses & & & \\
\hline & & $\begin{array}{l}\text { Optical } \\
\text { microscopes }\end{array}$ & 3 & $\begin{array}{l}\text { Testing methods } \\
\text { for optical } \\
\text { elements and } \\
\text { systems }\end{array}$ & 3 & & \\
\hline & & Image processing & 3 & $\begin{array}{l}\text { Constructing and } \\
\text { development of } \\
\text { opto-information } \\
\text { systems }\end{array}$ & 3 & & \\
\hline
\end{tabular}



TOTAL $\quad 120$

WORKLOAD

Figure 3. DDP structure [4] 
The second enrollment in 2014 differed in a high competition level among ITMO attendees. After entrance examinations and portfolio contest two from nine attendees were enrolled to the DDP. Two students from the WUT were enrolled to the DDP in 2014 as well. Thus, four students from both Universities started their studies. Remarkably, the WUT students are interested in the DDP due to the Poland job market demands in the "Optical Design" professional area. Both WUT students are sponsored by companies for which they will work in future. Motivation of the ITMO students is based mainly on a desire for studying in an international environment with application of modern educational technologies and equipment.

In general, according to responses of the ACO students and teaching staff, the DDP has become a stimulus for the transition to a new quality level of education due to reconsideration and reorientation of course contents, bringing relevance to research and internship topics in accordance with the world job market demands, application of modern specialized software and up-to-date laboratory equipment, training in international environment, and cooperation with partner scholars.

\section{CONCLUSION}

ITMO and WUT Universities find that mutual cooperation in education is fruitful and prospective. First outcomes of the DDP "Optical Design" are positive and promising. The main features of this initiative are excellent in matching the job market and skillful usage of expertise and resources of both Universities.

Development of a joint network PhD program will be the next step. At the same time the cooperation will be expanded with advancement of joint research projects, academic exchange programs, short-term educational programs etc.

\section{REFERENCES}

[1] ITMO University en.ifmo.ru

[2] OPSCITECH Optics in Science and Technology (1 May 2015)

eacea.ec.europa.eu/erasmus_mundus/results_compendia/documents/projects/action_1_master_courses/opscitech_mc.pdf

[3] Warsaw University of Technology https://www.cwm.pw.edu.pl/index.php/en

[4] Department of Applied and Computer Optics, ITMO University aco.ifmo.ru/education_eng.html 